\title{
Australian Journal of Crop Science \\ Genetic parameters of agronomic and nutritional traits of common bean (Phaseolus vulgaris L.) populations with biofortified grains
}

\author{
Sandra Maria Maziero, Nerinéia Dalfollo Ribeiro*, Hector dos Santos Facco \\ UFSM-Santa Maria Federal University, Crop Breeding Sector, Plant Science Department, Santa Maria, RS, \\ Brazil
}

\section{*Corresponding author: nerineia@hotmail.com}

\begin{abstract}
The objective of this study was to estimate genetic parameters for agronomic and nutritional traits in four common bean populations with biofortified grains for minerals, and to identify the superior population for these traits. Thus, four common bean populations were obtained by controlled crossings between parents contrasting for potassium $\left(\mathrm{P}_{1}\right)$, phosphorus $\left(\mathrm{P}_{2}\right)$, zinc $\left(\mathrm{P}_{3}\right)$ and copper $\left(\mathrm{P}_{4}\right)$. A total of 40 lines in $\mathrm{F}_{6: 8}$ generation of each population and nine parents were evaluated in two field experiments (rainy season of 2012 and dry season of 2013) in the state of Rio Grande do Sul, Brazil. The studied populations presented genetic variability for cycle, insertion of the first pod, grain yield, and potassium, phosphorus and zinc concentrations in grains. Heritability estimates and selection gain of intermediate and high magnitude were obtained for cycle, insertion of the first pod, grain yield, and potassium concentration in grains in $\mathrm{P}_{2}$. In $\mathrm{P}_{4}$, insertion of the first pod, grain yield and phosphorus and zinc concentrations in grains presented high heritability and selection gain estimates. From the tested crossings, it is possible to select common bean inbred lines biofortified for potassium, phosphorus and zinc and with high agronomic performance.
\end{abstract}

Keywords: agronomic performance; heritability; line x environment interaction; minerals; Phaseolus vulgaris; selection. Abbreviations: $\mathrm{P}_{1}$ segregating population for potassium, $\mathrm{P}_{2}$ segregating population for phosphorus, $\mathrm{P}_{3-}$ segregating population for zinc, $\mathrm{P}_{4-}$ segregating population for copper

\section{Introduction}

Brazil is a major producer of beans, wherein in the rainy season of 2012, 2.8 thousand tons of grains were produced in an area of 3.1 million hectares (CONAB, 2014). In this scenario, the development of bean cultivars with erect plant architecture, early cycle and high grain yield represents technological advantages for bean farmers. In addition, the possibility of adding nutritional value to the high agronomic performance of bean cultivars is a recent trend in breeding programs. Genetic biofortification of food crops is an important strategy to combat deficiencies of iron, zinc, vitamin $\mathrm{A}$ and $\mathrm{E}$ in humans (Prasad, 2012). Bean presents high mineral concentration in grains (Ribeiro et al., 2008; Tryphone and Nchimbi-Msolla, 2010; Silva et al., 2012; Ribeiro et al., 2013). Bean grains do not require milling, polishing, pearling or decortication in the processing, as cereal grains. Therefore, bean grains are high potential for mineral biofortification. Iron and zinc deficiencies affect about $40 \%$ and $33 \%$, respectively, of the people in the world (The Word Bank, 2006). The potential of beans for biofortification for iron and zinc has been evaluated, and the obtained results are promising (Blair, 2013; Jost et al., 2013; Petry et al., 2015; Teixeira et al., 2015). Biofortification for potassium, phosphorus and copper has not been reported in the literature for beans. Biofortification for potassium is important since higher potassium intake causes decrease in blood pressure, reduces cardiovascular diseases, and enables prevent the development of diabetes (Intersalt, 1986; He and MacGregor, 2008).
Phosphorus and copper deficiencies are unusual in humans. However, symptoms as painful bones, irregular breathing, fatigue, anxiety, numbness, skin sensitivity and changes in body weight have been described in cases of phosphorus deficiency (Martínez-Ballesta et al., 2010). Copper deficiency can cause several hematological symptoms, such as normocytic, hypochromic anemia, leucopenia and neutropenia, and skeletal disturbances (Guerrero-Romero and Rodríguez-Morán, 2005; Huskisson et al., 2007). Currently, over two billion people worldwide suffer from "hidden hunger", a term used to describe malnutrition of nutrients (Kennedy et al., 2003). In this scenario, the biofortification of beans for iron, zinc, potassium, phosphorus and copper is a promising practice to improve human's health. Common bean inbred lines with high iron and zinc concentrations in grains were obtained by plant breeding (Blair, 2013; Jost et al., 2013; Pereira et al., 2014; Teixeira et al., 2015). Preliminary studies showed that it was possible to increase phosphorus and copper concentrations in common bean grains in 19.17 and $46.78 \%$, respectively, in $F_{2}$ generation (Ribeiro et al., 2011; Poersch et al., 2013). Since common bean is self-fertilizing, is it expected that these values are reduced in each self-fertilizing generation. For this reason, the evaluation in advanced generations will be necessary to assess segregation for this trait. Since selection of superior common bean inbred lines for agronomic performance and mineral concentration in grains is efficient, it is necessary to know the magnitude of genetic parameters estimates. In common bean inbred lines, it was obtained high heritability 
for cycle (Faleiro et al., 2002), insertion of the first pod (Ribeiro et al., 2009; Jost et al., 2013), grain yield (Ribeiro et al., 2009; Torga et al., 2010; Jost et al., 2013), and zinc concentration (Teixeira et al., 2015). For potassium, phosphorus and copper concentrations in common bean, the genetic parameters estimates are restricted to early generations. Narrow-sense heritability was of high magnitude for phosphorus and copper concentrations in common bean grains in $\mathrm{F}_{2}$ generations (Ribeiro et al., 2011; Poersch et al., 2013), and of low magnitude for potassium concentration (Poersch et al., 2011).

Genetic parameter estimates are important to identify the nature of the action of genes involved in the control of quantitative traits, and enables the evaluation of the efficiency of different breeding strategies for obtaining genetic gains and maintaining the genetic variability (Cruz and Carneiro, 2006). Genetic parameter estimates for potassium, phosphorus and copper concentrations in common bean inbred lines were not found in the literature. Therefore, the objective of this study was to estimate genetic parameters for agronomic and nutritional traits in four common bean populations with biofortified grains for minerals, and to identify the superior population for these traits.

\section{Results}

\section{Analysis of variance for agronomic and nutritional traits}

The efficiency of the simple lattice design compared to randomized block design varied from 99.88 (cycle) to $120.95 \%$ (phosphorus concentration) (Table 2), and can be considered low. Thus, to correct the effect of blocks within each replicate, variance analysis was carried out in randomized block design. For this, adjusted mean squares of treatments and effective error of the lattice were used.

Furthermore, variance of the experimental error for the two growing seasons was homogeneous. Thus, the joint variance analysis for all traits was carried out. Cycle, insertion of the first pod, grain yield, and zinc concentration in grains presented significant treatment $x$ environment and line $x$ environment interactions (Table 2). For these traits, parent $\times$ environment interaction was also significant, except for zinc concentration. For potassium and phosphorus concentrations, significant interaction was observed only for treatment $x$ environment. On the other hand, for copper concentration in grains, the main effects and interactions tested were not significant in most cases; therefore, this mineral was not used to obtain estimates of genetic parameters. Considering the decomposition of line effect within population (L/P), significant differences were observed for all traits, except for copper concentration (Table 2). In addition, within each population, it was found that there is genetic variability among common bean lines for most populations and traits, except for copper concentration.

\section{Genetic parameters of agronomic and nutritional traits in beans}

Heritability estimates for cycle ranged from $49.7\left(\mathrm{P}_{4}\right)$ to $74.7 \%\left(\mathrm{P}_{2}\right)$ (Table 3), and were considered of intermediate to high magnitude. These estimates correspond to narrow-sense heritability, since they were determined in $\mathrm{F}_{6: 8}$ generation, which presents high homozygosis.

Selection of common bean lines with differentiated cycle is promising in population $2\left(\mathrm{P}_{2}\right)$, considering the genetic parameters estimates obtained for cycle in magnitude and sign. This population had the highest heritability $\left(h^{2}=74.7 \%\right)$ and CVg (3.9\%) estimates for cycle among the evaluated populations. $\mathrm{CVg} / \mathrm{CV}$ e ratio was the closest to the unit in $\mathrm{P}_{2}$, and the highest estimate of selection gain for cycle was obtained in $\mathrm{P}_{2}(\mathrm{SG}=-4.1 \%)$. In $\mathrm{P}_{2}$, it is possible to select common bean lines with intermediate cycle, similar to parents cultivars with shorter cycle: Guapo Brilhante, TPS Nobre and TPS Bonito (Table 4). Also, it is possible to selected lines with longer cycle, compared to parents cultivars (Tables 3 and 4).

Heritability of the insertion of the first pod presented from intermediate $\left(56.4 \%\right.$ in $\left.\mathrm{P}_{3}\right)$ to high magnitude $\left(71.1 \%\right.$ in $\left.\mathrm{P}_{4}\right)$ (Table 3). The highest genetic variance values for the insertion of the first pod were found in $\mathrm{P}_{2}$ and $\mathrm{P}_{4}$. These populations also presented the highest heritability $\left(h^{2}=69.4\right.$ and $71.1 \%$ ) and selection gain ( $\mathrm{SG}=13.3$ and $12.8 \%)$ estimates for the insertion of the first pod, indicating favorable conditions for selection. For grain yield, it was obtained high heritability estimates, of 62.6 to $81.5 \%$ (Table 3). In $P_{1}, P_{2}$ and $P_{4}$ populations, it was obtained selection gain estimates superior to $23.2 \%$ for grain yield. In these three populations, the mean of the five lines selected for grain yield was higher than that of Pérola cultivar, which was the parent with the highest grain yield (Table 4). Potassium concentration in common bean grains in $\mathrm{F}_{6: 8}$ generation had low to intermediate heritability $\left(h^{2}=28.8\right.$ to $59.1 \%$ ) (Table 3 ). The highest heritability and selection gain values obtained for potassium concentration were observed in $\mathrm{P}_{2}\left(h^{2}=59.1 \%\right.$ and $\mathrm{SG}=6.1 \%$ ), indicating greater chances of success if selection is carried out in this population. However, when considering the range of minimum and maximum values for potassium concentration in grains, it is possible to select common bean lines with high potassium concentration in any of the populations evaluated (Table 3 ). The heritability of phosphorus and zinc concentrations $\left(h^{2}=23.9\right.$ to $61.9 \%$, and $h^{2}=21.8$ to $64.3 \%$, respectively) varied from low to high magnitude (Table 3 ). $\mathrm{P}_{4}$ is the most suitable population for selection of common bean lines with biofortified grains for phosphorus and zinc, due to higher heritability and selection gain obtained for these traits.

\section{Discussion}

The common bean lines responded differently to changes in farming environments, because a significant treatment $\times$ environment, line $\times$ environment, and parent $\times$ environment interactions were observed for cycle, insertion of the first pod and grain yield. Significant genotype $\times$ environment interaction was previously described for cycle (Ribeiro et al., 2004), insertion of the first pod (Moura et al., 2013), grain yield (Ribeiro et al., 2008; Moura et al., 2013; Ribeiro et al., 2013), and zinc concentration (Cichy et al., 2005; Ribeiro et al., 2008; Silva et al., 2012) in experiments that evaluated bean lines performance. This represents difficulties in the selection of superior lines for traits that confer high agronomic performance and nutritional quality to beans. For this, breeding programs need to evaluate inbred lines in different environments before registering them as new common bean cultivars.

The evaluated inbred lines presented genetic variability for all traits, except for copper concentration in grains. However, in the $\mathrm{F}_{2}$ generation, it was observed wide genetic variability for copper concentration in the recombinant obtained from crossings between the common bean cultivars IAPAR $44 \times$ IAPAR 31, and between Diamante Negro $\times$ TPS Bonito (Poersch et al., 2013). In the present study, the variation coefficient obtained for copper concentration was of high magnitude $(\mathrm{CV}=33.18 \%)$, providing low experimental accuracy, and it did not allow the differentiation between common bean inbred lines for this mineral. Therefore, from 
the crossings tested in this study, it is possible to select common bean inbred lines with differentiated cycle duration and which are superior regarding insertion of the first pod, grain yield, and potassium, phosphorus and zinc concentrations in grains.

Cycle presented intermediate to high heritability in common bean lines in $\mathrm{F}_{6: 8}$ generation. In inbred lines, heritability was estimated in narrow-sense, since variation corresponds to the variability resulting from additive gene action (Ribeiro et al., 2009). Similar heritability values were obtained for cycle determined in 154 common bean lines in $\mathrm{F}_{8}$ generation (Faleiro et al., 2002). However, Jost et al. (2014) observed lower estimates values for cycle in 272 common bean lines in $F_{7}$ generation. The observed differences may be justified by the range of variation observed for cycle in the lines evaluated in different populations, by the experimental design (Faleiro et al., 2002), and by the method of advance of segregating generations (Jost et al., 2014).

Selection of common bean inbred lines with differentiated cycle in $\mathrm{P}_{2}$ may be effective by fixing of this trait in the next selection cycles. This is because this population had the highest heritability estimate for cycle, which indicates that genetic variance was mostly formed by additive variance. Additionally, $\mathrm{CVg}$ presents the highest magnitude among populations evaluated for cycle. $\mathrm{CVg}$ provides an idea regarding the proportionality of the gain in relation to the mean in the case of selection (Faleiro et al., 2002), and it is an estimate that needs to be considered by the breeder. $\mathrm{CVg} / \mathrm{CVe}$ ratio was the closest to the unit in $\mathrm{P}_{2}$, indicating that in this population, environmental effects were less significant among the evaluated populations, which favors selection. The highest selection gain estimate for cycle was obtained at $\mathrm{P}_{2}$. In this case, the negative value indicates a shorter cycle, which is of great interest for the Bean Breeding Program of UFSM.

Heritability estimates from $56.4 \%$ in $\mathrm{P}_{3}$ to $71.1 \%$ in $\mathrm{P}_{4}$ for insertion of the first pod were obtained. Therefore, insertion of the first pod showed little uncontrollable variation, which favors the selection of common bean inbred lines with higher values for this trait, which is in agreement with previous results obtained by Ribeiro et al. (2009) and Jost et al. (2013). Insertion of the first pod varied from $11.6 \mathrm{~cm}\left(\mathrm{P}_{3}\right)$ to $22.6 \mathrm{~m}$ $\left(\mathrm{P}_{1}\right)$. Thus, it is possible to select common bean inbred lines with plant standard that allows mechanized harvesting in all the evaluated populations. This is because plants with insertion of the first pod superior to $9.3 \mathrm{~cm}$ favor the direct harvest of beans with combine harvester (Silva et al., 2009). Identification of common bean lines with higher insertion of the first pod is important for the breeding program for representing marketing advantages to beans producers.

Grain yield showed high heritability estimates in $F_{6: 8}$ generation. High heritability values for this trait were not expected, since, according to Ramalho et al. (1993), grain yield in common bean presents quantitative inheritance. However, the magnitude of heritability estimates for grain yield obtained in the present study were similar to those values previously described for grain yield in common bean lines in $\mathrm{F}_{7}$ generation (Ribeiro et al., 2009; Jost et al., 2014), and $F_{3: 7}$ (Torga et al., 2010). Thus, despite the fact that it was used parents that had already been selected, and some cultivars have already been grown by farmers in the present study, genetic variability and selection gains ranging from $14.1\left(\mathrm{P}_{3}\right)$ to $25.4 \%\left(\mathrm{P}_{1}\right)$ were obtained for grain yield.

In this study, genetic parameter estimates were obtained using the mean data obtained for each trait in two growing seasons; thus, greater accuracy in selecting superior lines is expected. Since the highest heritability and selection gain estimates for grain yield were recorded in $\mathrm{P}_{1}, \mathrm{P}_{2}$ and $\mathrm{P}_{4}$, selection of superior lines is recommended in these populations, since there is a greater expectation of success.

Mineral concentration heritability in common bean grains varied from intermediate to high magnitude for potassium, phosphorus, and zinc in $\mathrm{F}_{6: 8}$ generation. Heritability estimates of potassium and phosphorus concentrations were not found in literature for common bean lines in advanced generations. However, at early generation, it was observed narrow-sense heritability estimates similar in magnitude for potassium (Poersch et al., 2011) and phosphorus (Ribeiro et al., 2011). High narrow-sense heritability was obtained for zinc concentration in common bean grains in $\mathrm{F}_{2}$ generation (Cichy et al., 2005; Rosa et al., 2010) and $\mathrm{F}_{3: 6}$ generation (Teixeira et al., 2015).

The mean of the five lines superior for potassium in the $\mathrm{P}_{1}$, $\mathrm{P}_{2}, \mathrm{P}_{3}$ and $\mathrm{P}_{4}$ was higher than the values recorded by Poersch et al. (2011) for this mineral in the $F_{2}$ generation. Therefore, from the tested crossings, it is possible to select common bean inbred lines with high potassium concentration in grains. Common bean inbred lines with biofortified grains for potassium could be incorporated to the diet in order to decrease the risk of occurrence of cardiovascular diseases and kidney stone formation, and also to prevent the development of diabetes (Intersalt, 1986; He and MacGregor, 2008).

When considering the selection of common bean inbred lines with biofortified grains for phosphorus and zinc, $\mathrm{P}_{4}$ is the most suitable population for selection of superior lines, due to higher heritability and selection gain obtained for these traits. However, mean values obtained for the five superior lines selected in each population were similar to the recombinants selected in the $\mathrm{F}_{2}$ generation by Ribeiro et al. (2011) for high phosphorus concentration in common bean grains. Since phosphorus is important in bone and teeth mineralization, and participates in energy metabolism (Oliveira, 2007), the use of common bean inbred lines with biofortified grains for phosphorus could be important to prevent symptoms as painful bones, irregular breathing, fatigue, anxiety, numbness and skin sensitivity (MartínezBallesta et al., 2010).

In relation to zinc concentration, the mean of the five superior lines for concentration of this mineral was equal to $32 \mathrm{mg} \mathrm{kg}^{-1}$ of dry matter in $\mathrm{P}_{2}, \mathrm{P}_{3}$ and $\mathrm{P}_{4}$, characterizing high zinc concentration in common bean grains according to the classification of Cichy et al. (2005) and Tryphone and Nchimbi-Msolla (2010). Common bean inbred lines with biofortified grains for zinc could be included in diets to improve the immune system efficacy and the sensibility of taste and smell senses (Guerrero-Romero and RodríguezMorán, 2005).

In the present study, selection of superior lines in population 2 favors to obtain new common bean cultivars with shorter cycle, higher insertion of the first pod, higher grain yield and higher potassium concentration in grains. Selection of superior lines in population 4 is promising for the development of new common bean cultivars with higher insertion of the first pod, higher grain yield and higher phosphorus and zinc concentrations in grains. Selection of common bean inbred lines with biofortified grains for potassium, phosphorus and zinc represents human health benefits due to the high nutritional value of this food. However, it is necessary to evaluate polyphenolic and phytate contents in the obtained populations, since these compounds, according to Ariza-Nieto et al. (2007) and Zhao and Shewry 
Table 1. Genealogy, seed coat colour and institution of origin of the parents used in the controlled crossings.

\begin{tabular}{llll}
\hline Parent & Genealogy* & Seed coat colour & Origin Institution \\
\hline IAPAR 44 & BAC 2/RAI 12//Rio Tibagi/Cornell 49242 & black & IAPAR \\
Guapo Brilhante & XAN 125 $\{$ BAT 336 (A83/ICA Pijao) & black & EMBRAPA \\
BRS Expedito & CNF 5491/FT Tarumã & black & EMBRAPA \\
BRS Valente & [(Emgopa 201-Ouro/Ônix)//AN 512586] & black & EMBRAPA \\
Pérola & Mass selection in Aporé cultivar & Beige with brown streaks & EMBRAPA \\
TPS Nobre & FT 120/FT 84-1806//FT 84-424 & black & FT Sementes \\
IAPAR 31 & BAC 4/RAI 46//BAC 2/IGUAÇÚ/3/BAT/BAC 4 & beige with brown spots & IAPAR \\
Diamante Negro & XAN 87/A 367 & black & EMBRAPA \\
TPS Bonito & IAPAR 44/IAC Carioca & beige with brown streaks & FT Sementes \\
\hline
\end{tabular}

*/: single crossing; //: double crossing.

Table 2. Joint variance analysis containing mean squares, degrees of freedom (DF) and mean values for cycle (days), insertion of the first pod (IFP, cm), grain yield (YIELD, $\left.\mathrm{kg} \mathrm{ha}^{-1}\right)$, potassium $\left(\mathrm{K}, \mathrm{g} \mathrm{kg}^{-1}\right.$ of dry matter - DM), phosphorus $\left(\mathrm{P}, \mathrm{g} \mathrm{kg}^{-1} \mathrm{DM}\right), \mathrm{zinc}^{\mathrm{Z}}\left(\mathrm{Zn}, \mathrm{mg}^{-}\right.$ $\left.\mathrm{kg}^{-1} \mathrm{DM}\right)$ and copper $\left(\mathrm{Cu}, \mathrm{mg} \mathrm{kg}^{-1} \mathrm{DM}\right)$ concentrations in grains of 160 common bean inbred lines and nine parents evaluated in rainy and dry seasons.

\begin{tabular}{|c|c|c|c|c|c|c|c|c|}
\hline \multirow[b]{2}{*}{ Sources of variation } & \multirow[b]{2}{*}{ DF } & \multicolumn{7}{|c|}{ Mean square } \\
\hline & & Cycle & IFP & YIELD & $\mathrm{K}$ & $P$ & $\mathrm{Zn}$ & $\mathrm{Cu}$ \\
\hline Treatment (T) & 168 & $51.55 * *$ & $18.68 * *$ & 468026.49 ** & $3.18 * *$ & 0.68 ** & $36.09 * *$ & $11.52^{\mathrm{ns}}$ \\
\hline Line (L) & 159 & $52.49 * *$ & $18.09 * *$ & $480897.54 * *$ & $3.33 * *$ & $0.61 * *$ & $38.63 * *$ & $13.00^{\mathrm{ns}}$ \\
\hline Population (P) & 3 & $218.45 * *$ & $171.00 * *$ & $1136523.58 * *$ & $6.31 * *$ & $0.28^{\mathrm{ns}}$ & $16.36^{\mathrm{ns}}$ & $25.72^{\mathrm{ns}}$ \\
\hline $\mathrm{L} / \mathrm{P}$ & 156 & $49.30 * *$ & $15.15 * *$ & $468289.35 * *$ & $3.27 * *$ & $0.62 * *$ & $39.06 * *$ & $12.75^{\mathrm{ns}}$ \\
\hline $\mathrm{L} / \mathrm{P}_{1}$ - Potassium & 39 & $47.28 * *$ & $14.95 * *$ & $514792.52 * *$ & $2.70 *$ & $0.74 * *$ & $21.18^{\text {ns }}$ & $9.41 \mathrm{~ns}$ \\
\hline L/P $/$ - Phosphorus & 39 & $74.21 * *$ & $17.58 * *$ & $496448.06 * *$ & $4.39 * *$ & $0.41^{\mathrm{ns}}$ & $36.01 * *$ & $9.25^{\mathrm{ns}}$ \\
\hline $\mathrm{L} / \mathrm{P}_{3}-$ Zinc & 39 & $52.79 * *$ & $8.90^{\mathrm{ns}}$ & $242569.66^{\mathrm{ns}}$ & $3.55 * *$ & $0.57 * *$ & $51.42 * *$ & $17.65 *$ \\
\hline $\mathrm{L} / \mathrm{P}_{4}-$ Copper & 39 & 22.92 ns & $19.17 * *$ & $619347.14 * *$ & $2.45^{\mathrm{ns}}$ & $0.76 * *$ & $47.63 * *$ & $14.69^{\mathrm{ns}}$ \\
\hline Parents (Pa) & 8 & $35.69 * *$ & $21.78 * *$ & $164786.19^{\mathrm{ns}}$ & $5.12 * *$ & $0.46^{\mathrm{ns}}$ & $13.52^{\text {ns }}$ & $14.11^{\mathrm{ns}}$ \\
\hline Group (Gr) & 1 & $53.39^{\text {ns }}$ & $52.58 * *$ & $636960.53 *$ & $1.12^{\mathrm{ns}}$ & $0.27^{\mathrm{ns}}$ & $2.03^{\mathrm{ns}}$ & $33.65^{\mathrm{ns}}$ \\
\hline Environment (E) & 1 & $112201.78 * *$ & $18449.89 * *$ & $11615546.69 * *$ & $88.20 * *$ & $16.88 * *$ & $9541.31 * *$ & $804.16 * *$ \\
\hline $\mathrm{T} \times \mathrm{E}$ & 168 & $36.49 * *$ & $14.02 * *$ & 380798.59 ** & $1.92 * *$ & $0.36 * *$ & $23.73 * *$ & $16.03^{\mathrm{ns}}$ \\
\hline $\mathrm{L} \times \mathrm{E}$ & 159 & $36.43 * *$ & $14.20 * *$ & $391097.75 * *$ & $2.14^{\mathrm{ns}}$ & $0.35^{\mathrm{ns}}$ & $23.50 *$ & $14.38^{\mathrm{ns}}$ \\
\hline $\mathrm{Pa} \times \mathrm{E}$ & 8 & $52.50 * *$ & $13.15 * *$ & $276812.44 *$ & $1.21^{\mathrm{ns}}$ & $0.29^{\mathrm{ns}}$ & $15.74^{\mathrm{ns}}$ & $25.27^{\mathrm{ns}}$ \\
\hline $\mathrm{Gr} \times \mathrm{E}$ & 1 & $40.61^{\text {ns }}$ & $5.41^{\mathrm{ns}}$ & $1071961.33 * *$ & $0.03^{\mathrm{ns}}$ & $1.56 *$ & $26.85^{\text {ns }}$ & $95.58 *$ \\
\hline Residue & 288 & 14.62 & 4.93 & 116475.00 & 1.34 & 0.26 & 17.42 & 10.38 \\
\hline $\mathrm{CV}(\%)^{(1)}$ & & 4.20 & 13.38 & 18.99 & 7.90 & 11.69 & 15.72 & 33.18 \\
\hline $\mathrm{EF}(\%)^{(2)}$ & & 99.88 & 101.62 & 107.15 & 116.94 & 120.95 & 104.26 & 114.57 \\
\hline
\end{tabular}

${ }^{(1)}$ Coefficient of variation. ${ }^{(2)}$ Efficiency of the lattice design (mean value of rainy and dry season). * and ** Significant by the $\mathrm{F}$ test at 0.05 and 0.01 probability, respectively. ${ }^{\text {ns }}$ Non-significant.

Table 3. Genetic parameters for cycle (days), insertion of the first pod (IFP $\mathrm{cm}$ ), grain yield (YIELD, $\mathrm{kg} \mathrm{ha}^{-1}$ ), potassium $\left(\mathrm{K}, \mathrm{g} \mathrm{kg}^{-1}\right.$ of dry matter - DM), phosphorus $\left(\mathrm{P}, \mathrm{g} \mathrm{kg}^{-1} \mathrm{DM}\right)$ and zinc $\left(\mathrm{Zn}, \mathrm{mg} \mathrm{kg}^{-1} \mathrm{DM}\right)$ concentrations in grains of four common bean populations (segregating populations for: potassium $-\mathrm{P}_{1}$, phosphorus $-\mathrm{P}_{2}$, zinc $-\mathrm{P}_{3}$, and copper $-\mathrm{P}_{4}$ ) evaluated in rainy and dry seasons.

\begin{tabular}{|c|c|c|c|c|c|c|c|c|c|c|c|c|}
\hline \multirow{2}{*}{ Genetic parameters } & \multicolumn{4}{|l|}{ Cycle } & \multicolumn{4}{|l|}{ IFP } & \multicolumn{4}{|l|}{ YIELD } \\
\hline & $\mathrm{P}_{1}$ & $\mathrm{P}_{2}$ & $\mathrm{P}_{3}$ & $\mathrm{P}_{4}$ & $\mathrm{P}_{1}$ & $\mathrm{P}_{2}$ & $\mathrm{P}_{3}$ & $\mathrm{P}_{4}$ & $\mathrm{P}_{1}$ & $\mathrm{P}_{2}$ & $\mathrm{P}_{3}$ & $\mathrm{P}_{4}$ \\
\hline$\sigma_{G}^{2}{ }^{(1)}$ & 8.4 & 13.9 & 9.5 & 2.8 & 2.6 & 3.1 & 1.3 & 3.4 & 94591.4 & 101155.2 & 37983.2 & 113015.5 \\
\hline$\sigma_{E}^{2}(2)$ & 13.7 & 18.8 & 15.0 & 11.5 & 4.6 & 5.4 & 3.9 & 5.5 & 136426.9 & 91827.2 & 90636.7 & 167285.1 \\
\hline $\mathrm{h}^{2}(\%)^{(3)}$ & 70.9 & 74.7 & 71.6 & 49.7 & 69.1 & 69.4 & 56.4 & 71.1 & 73.5 & 81.5 & 62.6 & 73.0 \\
\hline $\operatorname{CVg}(\%)^{(4)}$ & 3.1 & 3.9 & 3.3 & 1.8 & 9.2 & 10.6 & 7.4 & 10.8 & 16.8 & 16.6 & 11.2 & 17.4 \\
\hline $\mathrm{CVe}(\%)^{(5)}$ & 4.0 & 4.6 & 4.2 & 3.7 & 12.3 & 14.1 & 13.0 & 13.7 & 20.1 & 15.8 & 17.2 & 21.2 \\
\hline $\mathrm{CVg} / \mathrm{CVe}$ ratio $^{(6)}$ & 0.8 & 0.9 & 0.8 & 0.5 & 0.7 & 0.8 & 0.6 & 0.8 & 0.8 & 1.0 & 0.6 & 0.8 \\
\hline Minimum value & 88.5 & 88.0 & 87.0 & 87.8 & 14.5 & 11.7 & 11.6 & 13.2 & 1267.4 & 1217.9 & 1286.5 & 1207.4 \\
\hline Maximum value & 103.3 & 105.3 & 105.8 & 97.3 & 22.6 & 21.2 & 18.0 & 21.8 & 3040.8 & 2582.7 & 2298.3 & 2713.4 \\
\hline Mean $5+{ }^{(7)}$ & 89.5 & 89.5 & 88.5 & 88.5 & 20.3 & 19.6 & 17.6 & 20.2 & 2468.5 & 2460.3 & 2140.7 & 2549.9 \\
\hline $\mathrm{SG}(\%)^{(8)}$ & -2.9 & -4.1 & -3.0 & -1.9 & 10.9 & 13.3 & 9.1 & 12.8 & 25.4 & 23.2 & 14.1 & 23.5 \\
\hline \multirow{2}{*}{ Genetic parameters } & \multicolumn{4}{|l|}{$\mathrm{K}$} & \multicolumn{4}{|l|}{$\mathrm{P}$} & \multicolumn{4}{|l|}{$\mathrm{Zn}$} \\
\hline & $\mathrm{P}_{1}$ & $\mathrm{P}_{2}$ & $\mathrm{P}_{3}$ & $\mathrm{P}_{4}$ & $\mathrm{P}_{1}$ & $\mathrm{P}_{2}$ & $\mathrm{P}_{3}$ & $\mathrm{P}_{4}$ & $\mathrm{P}_{1}$ & $\mathrm{P}_{2}$ & $\mathrm{P}_{3}$ & $\mathrm{P}_{4}$ \\
\hline$\sigma_{G}^{2}{ }^{(1)}$ & 0.2 & 0.6 & 0.5 & 0.2 & 0.1 & 0.0 & 0.1 & 0.1 & 1.2 & 4.5 & 7.6 & 7.7 \\
\hline$\sigma_{E}^{2}(2)$ & 1.8 & $\begin{array}{l}0.0 \\
1.8\end{array}$ & 1.5 & 1.7 & 0.5 & 0.3 & 0.3 & 0.3 & 16.6 & 18.2 & 21.0 & 17.0 \\
\hline $\mathrm{h}^{2}(\%)^{(3)}$ & 34.2 & 59.1 & 56.4 & 28.8 & 38.5 & 23.9 & 52.0 & 61.9 & 21.8 & 49.6 & 59.1 & 64.3 \\
\hline $\operatorname{CVg}(\%)^{(4)}$ & 2.9 & 4.9 & 4.2 & 2.5 & 5.4 & 3.2 & 5.6 & 7.0 & 4.0 & 7.7 & 10.1 & 10.1 \\
\hline $\mathrm{CVe}(\%)^{(5)}$ & 8.0 & 8.1 & 7.3 & 7.9 & 13.6 & 11.3 & 10.8 & 11.0 & 15.2 & 15.5 & 16.8 & 15.0 \\
\hline $\mathrm{CVg} / \mathrm{CVe}$ ratio $^{(6)}$ & 0.4 & 0.6 & 0.6 & 0.3 & 0.4 & 0.3 & 0.5 & 0.6 & 0.3 & 0.5 & 0.6 & 0.7 \\
\hline Minimum value & 15.1 & 15.1 & 15.3 & 15.5 & 4.1 & 4.2 & 4.1 & 4.2 & 22.6 & 22.4 & 20.3 & 20.5 \\
\hline Maximum value & 18.2 & 19.6 & 18.8 & 18.6 & 5.8 & 5.6 & 5.6 & 5.9 & 32.9 & 34.6 & 36.0 & 35.5 \\
\hline Mean $5+{ }^{(7)}$ & 17.9 & 18.2 & 18.5 & 18.0 & 5.6 & 5.4 & 5.3 & 5.7 & 29.8 & 32.7 & 32.0 & 32.6 \\
\hline SG $(\%)^{(8)}$ & 2.6 & 6.1 & 5.2 & 2.2 & 4.8 & 2.2 & 4.2 & 10.4 & 2.4 & 9.5 & 10.0 & 11.9 \\
\hline
\end{tabular}


Table 4. Mean values for populations and parents for cycle, insertion of the first pod (IFP), grain yield (YIELD), potassium (K, $g$ kg ${ }^{1}$ of dry matter - DM), phosphorus $(\mathrm{P})$, and zinc $(\mathrm{Zn})$ concentrations evaluated in rainy and dry seasons.

\begin{tabular}{|c|c|c|c|c|c|c|}
\hline \multirow{3}{*}{ Population } & \multicolumn{6}{|c|}{ Mean values for population ${ }^{5}$} \\
\hline & CYCLE & IFP & YIELD & K & $P$ & $\mathrm{Zn}$ \\
\hline & (days) & $(\mathrm{cm})$ & $\left(\mathrm{kg} \mathrm{ha}^{-1}\right)$ & $\left(\mathrm{g} \mathrm{kg}^{-1}\right.$ of $\left.\mathrm{DM}\right)$ & $\left(\mathrm{g} \mathrm{kg}^{-1}\right.$ of $\left.\mathrm{DM}\right)$ & $\left(\mathrm{mg} \mathrm{kg}^{-1}\right.$ of $\left.\mathrm{DM}\right)$ \\
\hline$\overline{\mathrm{P}_{1}^{(1)}}$ & $93.3 \mathrm{ab}$ & $17.5 \mathrm{a}$ & $1834.1 \mathrm{a}$ & $16.7 \mathrm{a}$ & 5.0 & 26.8 \\
\hline $\mathrm{P}_{2}^{(2)}$ & $94.7 \mathrm{a}$ & $16.5 \mathrm{~b}$ & $1915.7 \mathrm{a}$ & $16.5 \mathrm{a}$ & 4.9 & 27.4 \\
\hline $\mathrm{P}_{3}{ }^{(3)}$ & $92.4 \mathrm{ab}$ & $15.2 \mathrm{c}$ & $1747.3 \mathrm{a}$ & $17.0 \mathrm{a}$ & 4.9 & 27.4 \\
\hline $\mathrm{P}_{4}^{(4)}$ & $92.1 \mathrm{~b}$ & $17.1 \mathrm{a}$ & 1929.8 a & $16.8 \mathrm{a}$ & 4.9 & 27.5 \\
\hline \multirow[t]{2}{*}{ Mean } & 93.1 & 16.6 & 1856.7 & 16.7 & 4.9 & 27.3 \\
\hline & \multicolumn{6}{|c|}{ Mean values for parent ${ }^{6}$} \\
\hline \multirow[t]{2}{*}{ Parent } & CYCLE & IFP & YIELD & K & $\mathrm{P}$ & $\mathrm{Zn}$ \\
\hline & (days) & $(\mathrm{cm})$ & $\left(\mathrm{kg} \mathrm{ha}^{-1}\right)$ & $\left(\mathrm{g} \mathrm{kg}^{-1}\right.$ of $\left.\mathrm{DM}\right)$ & $\left(\mathrm{g} \mathrm{kg}^{-1}\right.$ of $\left.\mathrm{DM}\right)$ & $\left(\mathrm{mg} \mathrm{kg}^{-1}\right.$ of DM) \\
\hline Guapo Brilhante & $91.0 \mathrm{~b}$ & $15.7 \mathrm{c}$ & 2177.9 & $14.6 \mathrm{~b}$ & 4.2 & 29.1 \\
\hline TPS Nobre & $91.0 \mathrm{~b}$ & $17.7 \mathrm{~b}$ & 1751.6 & $16.9 \mathrm{a}$ & 4.6 & 29.0 \\
\hline BRS Expedito & $95.8 \mathrm{a}$ & $18.2 \mathrm{~b}$ & 2084.6 & $18.0 \mathrm{a}$ & 5.2 & 29.2 \\
\hline IAPAR 44 & $94.3 \mathrm{a}$ & $16.9 \mathrm{~b}$ & 2022.0 & $17.5 \mathrm{a}$ & 4.8 & 26.7 \\
\hline BRS Valente & 96.8 a & $18.6 \mathrm{~b}$ & 1814.0 & $17.6 \mathrm{a}$ & 5.2 & 24.1 \\
\hline TPS Bonito & $90.0 \mathrm{~b}$ & $13.8 \mathrm{c}$ & 2108.0 & $17.4 \mathrm{a}$ & 4.7 & 28.8 \\
\hline IAPAR 31 & $95.5 \mathrm{a}$ & $19.5 \mathrm{a}$ & 1945.3 & $15.9 \mathrm{~b}$ & 4.7 & 27.6 \\
\hline Diamante Negro & 96.8 a & $17.9 \mathrm{~b}$ & 1719.5 & $17.9 \mathrm{a}$ & 5.3 & 25.2 \\
\hline Pérola & 98.3 a & $22.1 \mathrm{a}$ & 2317.9 & $16.3 \mathrm{~b}$ & 4.7 & 28.0 \\
\hline Mean & 94.4 & 17.8 & 1993.4 & 16.9 & 4.8 & 27.5 \\
\hline
\end{tabular}

(2011), could reduce phosphorus, zinc and iron absorption and bioavailability.

\section{Materials and Methods}

\section{Plant material and advanced generations}

Four common bean populations with biofortified grains for potassium (population $1-\mathrm{P}_{1}$ ), phosphorus (population $2-\mathrm{P}_{2}$ ), zinc (population $3-\mathrm{P}_{3}$ ) and copper (population $4-\mathrm{P}_{4}$ ) were obtained by Poersch et al. (2011), Ribeiro et al. (2011), Rosa et al. (2010), and Poersch et al. (2013), respectively. For this, controlled crossings were carried out between the cultivars IAPAR $44 \times$ Guapo Brilhante, and BRS Expedito $\times$ BRS Valente $\left(\mathrm{P}_{1}\right)$, Pérola $\times$ Guapo Brilhante, and TPS Nobre $\times$ Guapo Brilhante $\left(\mathrm{P}_{2}\right.$ and $\left.\mathrm{P}_{3}\right)$, and IAPAR $44 \times$ IAPAR 31, and Diamante Negro $\times$ TPS Bonito $\left(\mathrm{P}_{4}\right)$ (Table 1). Segregating generations were advanced using the SingleSeed Descent method (SSD). Seeds obtained in each of these plants were collected individually and stored in paper bags in a cold chamber $\left(2{ }^{\circ} \mathrm{C}\right.$ and $70 \%$ relative humidity) for three months. In the rainy season of 2011 , the $288 \mathrm{~F}_{6: 7}$ lines and nine parents were advanced in an experiment carried out in augmented block design with four replications. This experiment was carried out in the field area of the Bean Breeding Program of UFSM, located in the city of Santa Maria, state of Rio Grande do Sul, Brazil (latitude 29 $42^{\prime} \mathrm{S}$, longitude $53^{\circ} 49^{\prime} \mathrm{W}$, at $95 \mathrm{~m}$ above sea level). The experimental plot consisted of one $2 \mathrm{~m}$ row, spaced $0.50 \mathrm{~m}$ apart, with 30 seeds.

\section{Evaluation of inbred lines}

$\mathrm{F}_{6: 8}$ lines were evaluated in two experiments carried out in the field area of the Bean Breeding Program of UFSM. The first experiment consisted of a $15 \times 15$ simple lattice design, with sowing in October 27, 2012 (rainy season), and the second experiment was carried out in a $13 \times 13$ simple lattice design, with sowing in March 02, 2013 (dry season). Each plot consisted of two $1 \mathrm{~m}$ rows, spaced $0.50 \mathrm{~m}$ apart, with 15 seeds per meter. The rainy season of the 2012's experiment was composed of 225 treatments, with $212 \mathrm{~F}_{6: 8}$ lines, nine parent cultivars and four control cultivars (BRS Campeiro, Carioca, FTS Magnífico and Rio Tibagi). In the dry season of the 2013's experiment, 169 treatments were evaluated, being $160 \mathrm{~F}_{6: 8}$ lines and nine parent cultivars. In the second experiment, the number of treatments was reduced due to the lack of seeds availability of some lines. Common treatments were evaluated in the experiments, being 40 lines of each of the four populations and the parents. Climate is Cfa humid subtropical with hot summers and no defined dry season, according to the Köppen classification. Soil is classified as typicall alitic Argisol, Hapludalf, and was prepared in conventional manner. The amounts of applied fertilizers were in accordance with the needs identified in the soil chemical analysis, and totaled $275 \mathrm{~kg} \mathrm{ha}^{-1}$ of the commercial formula 5-20-20 (5\% nitrogen, $20 \%$ phosphate and $20 \%$ potassium) applied at furrow sowing, and $20 \mathrm{~kg} \mathrm{ha}^{-1}$ of urea $(45 \%$ nitrogen) applied in the growth stage of the first trifoliate leaf (V3). Thiamethoxam and Lambda-cyhalothrin $\left(100 \mathrm{ml} \mathrm{ha}^{-1}\right)$ insecticides were used to control Diabrotica speciosa when it was found 20 insects per beating cloth. Weeds were mechanically removed (with a hoe) when necessary, in order to avoid competition with the crop. Disease control was not carried out. The cycle - number of days from emergence to maturity - was evaluated when half plus one of the plants in the experimental unit reached stage R9 (maturation), i.e., when pods lost their pigmentation and began to dry. Insertion of the first pod was measured in 10 plants randomly collected in the experimental unit. For this, the distance from ground level to the insertion of the first pod was measured, but it did not consider the lodging degree of the plant. The other plants of the experimental unit were manually harvested in order to determine grain yield, which was carried out by calculating the weight of the product obtained in all the experimental unit per hectare, at $13 \%$ of average humidity. Covariance - Ideal Stand method, described by Schmildt et al. (2001), was used for correction of grain yield due to the heterogeneity of plant stand. Mineral concentration was determined in random samples of $500 \mathrm{~g}$ grains of the $\mathrm{F}_{6: 8}$ line and of parents from 
each replication, in each growing season. Grains were ground in a micro-mill (Q298A21, Quimis, Diadema, São Paulo, Brazil), to produce particles smaller than $1 \mathrm{~mm}$ in diameter. In the raw bean flour obtained, it was used $0.5 \mathrm{~g}$ of the sample for nitric-perchloric digestion ( $\mathrm{HNO} 3+\mathrm{HClO} 4$, in a $3: 1$ ratio by volume), according to the method described by Jost et al. (2013). Minerals were determined by flame photometer (B642, Micronal, São Paulo, São Paulo, Brazil) for potassium concentration, and by UV-VIS spectrophotometer with a capacity of eight cuvettes (UVVisible Spectrophotometer T60, PG Instruments Ltd., Leicestershire, UK), at wavelengths of $600 \mathrm{~nm}$, for phosphorus concentration. Zinc and copper concentrations were quantified using an atomic absorption spectrophotometer (XplorAA DUAL, GBC Scientific Equipment Pty. Ltd., Braeside, Australia) at wavelengths of $213.9 \mathrm{~nm}$ and $324.8 \mathrm{~nm}$, respectively.

\section{Statistical analysis and estimates of genetic parameters}

Data normality was verified using the Kolmogorov-Smirnov test at 0.05 probability. Individual variance analysis was carried out considering the simple lattice design. Efficiency of the simple lattice design in relation to the randomized block design was determined by the formula:

$\mathrm{Ef}=\left(\mathrm{MSR}_{\mathrm{R}} / \mathrm{V}_{\mathrm{r}}\right) \times 100$

Where; $\mathrm{MS}_{\mathrm{R}}$ is the mean square of residue analysis of lattice as randomized block design, and $\mathrm{V}_{\mathrm{r}}$ is the mean effective variance of simple lattice analysis with recovery of interblock information. Joint variance analysis was carried out with the treatments common to both experiments, according to the randomized block design, but using adjusted treatment and the effective error of the simple lattice design to correct the effect of blocks. Effects of treatments and experimental error were considered as random, and effects of environment and genotype $\times$ environment interaction, as fixed. Homogeneity of residual variances was verified by the Hartley's maximum $F$ test. Effect of treatments was decomposed in lines and parents, and hierarchical method was used to evaluate the effect of lines within each population. The following genetic parameters were estimated in each population: genetic variance, environmental variance, heritability $\left(\mathrm{h}^{2}\right)$, coefficient of genetic variation $(\mathrm{CVg})$, coefficient of environmental variation (CVe), $\mathrm{CVg} / \mathrm{CVe}$ ratio, minimum value, maximum value, mean of the five superior lines, and selection gain (SG). Heritability was calculated based on the components of variance, using the means of treatments, by the formula

$$
\mathrm{h}^{2}=\frac{\hat{\sigma}_{\mathrm{T}}^{2}}{\hat{\sigma}_{\overline{\mathrm{F}}}^{2}}=\frac{\hat{\sigma}_{\mathrm{T}}^{2}}{\hat{\sigma}_{\mathrm{T}}^{2}+\frac{\hat{\sigma}_{\mathrm{TA}}^{2}}{\mathrm{~L}}+\frac{\hat{\sigma}^{2}}{\mathrm{JL}}}
$$

where $\hat{\sigma}_{\mathrm{T}}^{2}$ is the genetic variance among treatments, which corresponds the additive genetic variance; $\hat{\sigma}_{\overline{\mathrm{F}}}^{2}$ is the phenotypic variance among means of treatments; $\hat{\sigma}_{\mathrm{TA}}^{2}$ is the treatment $\mathrm{x}$ growing season interaction variance; $\hat{\sigma}^{2}$ is the residual variance; $\mathrm{L}$ is the growing season number; and $\mathrm{J}$ is the number of blocks.

Selection gain for each trait was estimated with the selection of the five lines with the best means for the trait, within each population, according to methodology described by Jost et al. (2013). The Tukey test at 0.05 probability was used for the comparison of means between populations. The
Scott-Knott test at 0.05 probability was used to group parents. Analyzis and mean test were carried out using the Genes Software (Cruz, 2013).

\section{Conclusion}

Cycle, insertion of the first pod, grain yield and potassium concentration in grains in population 2 presents heritability and selection gain estimates of intermediate to high magnitude. Insertion of the first pod, grain yield and phosphorus and zinc concentrations in grains present high heritability and selection gain in population 4. From the crossings tested, it is possible to select common bean lines biofortified for potassium, phosphorus and zinc, and with high agronomic performance.

\section{Acknowledgements}

We thank the Coordination for the Improvement of Higher Education Personnel (CAPES) and the National Council of Technological and Scientific Development (CNPq) for the grants awarded. The authors would also like to thank Mr. Euzébio Maziero for his assistance in conducting experiments.

\section{References}

Ariza-Nieto M, Blair MW, Welch RM, Glahn P (2007) Screening of iron biovailability patterns in eight bean (Phaseolus vulgaris L.) genotypes using the caco-2 cell in vitro model. J Agr Food Chem. 55: 7950-79567.

Blair MW (2013) Mineral biofortification strategies for food staples: the example of common bean. J Agr Food Chem. 61: 8287-8294.

Cichy KA, Forster S, Grafton KF, Hosfield GL (2005) Inheritance of seed zinc accumulation in navy bean. Crop Sci. 45: 864-870.

CONAB (2014) Companhia Nacional de Abastecimento. Séries históricas: feijão $1^{\mathrm{a}}, 2^{\mathrm{a}}$ e $3^{\mathrm{a}}$ safra. http: // www. conab. gov. br

Cruz CD (2013) Genes - a software package for analysis in experimental statistics and quantitative genetics. Acta SciAgron. 35: 271-276.

Cruz CD, Carneiro PCS (2006) Modelos biométricos aplicados ao melhoramento genético. Universidade Federal de Viçosa, Viçosa.

Faleiro FG, Cruz CD, Castro C, Moreira MA, Barros EG (2002) Comparação de blocos casualizados e testemunhas intercalares na estimação de parâmetros genéticos em feijoeiro. Pesqui Agropecu Bras. 37: 1675-1680.

Guerrero-Romero F, Rodríguez-Morán M (2005) Complementary therapies for diabets: the case for chromium, magnesium, and antioxidants. Arch Med Res. 36: 250-257.

He FJ, MacGregor GA (2008) Beneficial effects of potassium on human health. Physiol Plantarum. 133: 725-735.

Huskisson E, Maggini S, Ruf M (2007) The role of vitamins and minerals in energy metabolism and well-being. $\mathrm{J}$ Int Med Res. 35: 277-289.

Kennedy G, Nantel G, Shetty P (2003) The scourge of "hidden hunger": global dimensions of micronutrient deficiencies. Food Nutr Agric. 32: 8-16.

INTERSALT (1986) Intersalt: an international study of electrolyte excretion and blood pressure. Results for 24 hour urinary sodium and potassium excretion. Brit Med J. 297: 319-328. 
Jost E, Ribeiro ND, Maziero SM, Possobom MTDF, Rosa DP, Domingues LS (2013) Comparison among direct, indirect and index selections on agronomic traits and nutritional quality traits in common bean. J Sci Food Agr. 93: 1097-1104.

Jost E, Ribeiro ND, Rosa DP, Possobom MTDF, Maziero SM (2014) Methods of selecting common bean lines having high yield, early cycle and erect growth. Rev Cienc Agron. 45: 101-110.

Martínez-Ballesta MC, Dominguez-Perles R, Moreno DA, Muries B, Alcaraz-López C, Batías E, García-Viguera C, Carvajal M (2010) Minerals in plant food: effect of agricultural practices and role in human health. A review. Agron Sustain Dev. 30: 295-309.

Moura MM, Carneiro PCS, Carneiro JES, Cruz CD (2013) Potencial de caracteres na avaliação da arquitetura de plantas de feijão. Pesqui Agropecu Bras. 48: 417-425.

Oliveira TC (2007) Fósforo: função, metabolismo e recomendações. Rev Dig Nut. 1: 1-24.

Pereira HS, Del Peloso MJ, Bassinello PZ, Guimarães CM, Melo LC, Faria LC (2014) Genetic variability for iron and zinc content in common bean lines and interaction with water availability. Genet Mol Res. 13: 6773-6785.

Petry N, Boy E, Wirth JP, Hurell RF (2015) The potential of the common bean (Phaseolus vulgaris) as a vehicle for iron biofortification. Nutrients. 7: 1144-1173.

Poersch NL, Ribeiro ND, Rosa DP, Possobom MTDF (2011) Genetic control of potassium content of common bean seeds. Pesqui Agropecu Bras. 46: 626-632.

Poersch NL, Ribeiro ND, Rosa DP, Maziero SM, Jost E (2013) Genetics of the concentration of copper in common bean seeds. Acta Sci-Agron. 35: 301-306.

Prasad R (2012) Micro mineral nutrient deficiencies in humans, animals and plants and their amelioration. P Natl Acad Sci USA. 82: 225-233.

Ramalho MAP, Santos JB, Zimmermann MJO (1993) Genética quantitativa em plantas autógamas: aplicações ao melhoramento do feijoeiro. Universidade Federal de Goiás, Goiânia.

Ribeiro EH, Pereira MG, Coelho KS, Freitas Júnior SP (2009) Estimativas de parâmetros genéticos e seleção de linhagens endogâmicas recombinantes de feijoeiro comum (Phaseolus vulgaris L.). Rev Ceres. 56: 580-590.

Ribeiro ND, Jost E, Cargnelutti Filho A (2004) Efeitos da interação genótipo $\mathrm{x}$ ambiente no ciclo e na coloração do tegumento dos grãos do feijoeiro comum. Bragantia. 63: 373-380.

Ribeiro ND, Jost E, Cerutti T, Maziero SM, Poersch NL (2008) Composição de microminerais em cultivares de feijão e aplicações para o melhoramento genético. Bragantia. 67: 267-273.

Ribeiro ND, Mambrin RB, Storck L, Prigol M, Nogueira CW (2013) Combined selection for grain yield, cooking quality and minerals in the common bean. Rev Cienc Agron. 44: 869-877.
Ribeiro ND, Rosa SS, Jost E, Rosa DP, Poersch NL, Maziero SM (2011) Genetics of phosphorus content in common bean seeds. Crop Breed Appl Biot. 11: 250-256.

Rosa SS, Ribeiro ND, Jost E, Reiniger LRS, Rosa DP, Cerutti T, Possobom MTDF (2010) Potential for increasing the zinc content in common bean using genetic improvement. Euphytica. 175: 207-213.

Schmildt ER, Cruz CD, Zanuncio JC, Pereira PRG, Ferrão RG (2001) Avaliação de métodos de correção do estande para estimar a produtividade em milho. Pesqui Agropecu Bras. 36: 1011-1018.

Silva CA, Abreu AFB, Ramalho MAP, Maia LGS (2012) Chemical composition as related to seed color of common bean. Crop Breed Appl Biot. 12: 132-137.

Silva JG, Aidar H, Kluthcouski J (2009) Colheita direta de feijão com colhedora automotriz axial. Pesqui Agropecu Trop. 39: 371-379.

Teixeira R de KS, Lima DC, Abreu A de FB and Ramalho MAP (2015) Implications of early selection for grain colour on iron and zinc content and productivity of common bean. Plant Breeding. 134: 193-196.

The World Bank (2006) Repositioning nutrition as central to development. A strategy for large-scale action. The International Bank for Reconstruction and Development/The World Bank, Washington.

Torga PP, Santos JB, Pereira HS, Ferreira DF, Leite ME (2010) Seleção de famílias de feijoeiro baseada na produtividade, no tipo de grãos e informações de QTLs. Cienc Agrotec. 34: 95-100.

Tryphone GM, Nchimbi-Msolla S (2010) Diversity of common bean (Phaseoelus vulgaris L.) genotypes in iron and zinc contents under screenhouse conditions. Afr J Agric Res. 5: 738-747.

Zhao F, Shewry PR (2011) Recent developments in modifying crops and agronomic practice to improve human health. Food Policy. 36: S94-S101. 